\title{
PENERAPAN MODEL PEMBELAJARAN PROJECT BASED LEARNING UNTUK MENINGKATKAN HASIL BELAJAR FISIKA DAN KETERAMPILAN PROSES SAINS PESERTA DIDIK KELAS X SMA N 2 TONDANO
}

\author{
Selty Anastasia Tindige, Jeane Cornelda Rende, Alfrits Komansilan \\ Fakultas Matematika dan Ilmu Pengetahuan Alam, Universitas Negeri Manado \\ email: seltytindige09@gmail.com
}

\begin{abstract}
ABSTRAK
Penelitian ini bertujuan untuk: 1) Untuk mengetahui peningkatan hasil belajar fisika siswa kelas X di SMA Negeri 2 Tondano dengan menggunakan model project based learning pada pokok bahasan Usaha dan Energi. 2) Untuk mengetahui peningkatan keterampilan proses sains fisika siswa kelas $\mathrm{X}$ di SMA Negeri 2 Tondano dengan menggunakan model project based learning pada pokok bahasan Usaha dan Energi. Jenis penelitian ini merupakan penelitian dengan menggunakan metode penelitian tindakan kelas (PTK) yang dilaksanakan 2 siklus dalam 4 tahap, yaitu: tahap Perencanaan (Planning),Pelaksanaan Tindakan(Action), Pengamatan (Observation), dan Refleksi (Reflection). Hasil penelitian adalah 1) penerapan model pembelajaran PjBL pada materi pokok usaha dan energi dapat meningkatkan hasil belajar fisika dan keterampilan proses sains peserta didik kelas X SMA N 2 Tondano. 2) Siklus I nilai gain-test sebesar 0,43dengan kategori sedang, siklus II nilai gaintest sebesar 0,51 dengan kategori sedang, 3) siklus I nilai rata-rata keterampilan proses sains sebesar 84,7 dengan kategori baik dan siklus II nilai rata-rata keterampilan proses sains sebesar 89,9 dengan kategori sangat baik.
\end{abstract}

Kata kunci : Project based learning, hasil belajar fisika, keterampilan proses belajar sains

\begin{abstract}
This study aims to: 1) To find out how to improve physics learning outcomes of Class $X$ students at SMA Negeri 2 Tondano, use a project-based learning model on effort and energy. 2) Determination of the improvement in the abilities of class $X$ students in physics processes at the SMA Negeri 2 Tondano using a project-based learning model, on the subject of effort and energy. This type of research is a research using the Classroom Action Research Method (PTK) done in 2 cycles in 4 stages, namely: planning phase, action, observation and reflection. The results of the study were 1) The application of the PjBL learning model on the subject of effort and energy can improve the learning outcomes of the physical and scientific process skills of the class X SMA N 2 Tondano. 2) Cycle I The gain test value was 0.43 in the medium category, Cycle II the gain test value was 0.51 in the moderate category. 3) In the first cycle the average value of the scientific process skills was 84.7 with a good category and cycle II the average value of the scientific process skills was 89.9 with a very good category.
\end{abstract}

Keywords : Project based learning model, learning outcomes in physics, skills in scientific processes 


\section{PENDAHULUAN}

Pendidikan merupakan salah satu bentuk upaya untuk meningkatkan kualitas sumber daya manusia. Pendidikan, dalam arti usaha sadar dan terencana mewujudkan proses belajar, menyentuh semua sendi kehidupan, semua lapisan masyarakat, dan segala usia.Pembangunan di suatu negara tidak bisa mengabaikan kegiatan pendidikan. Masa depan suatu negara sangat ditentukan oleh bagaimana negara itu memperlakukan pendidikan (Yamin \& Antasari, 2008).

Proses pembelajaran merupakan suatu sistem. Dengan demikian, pencapaian standar proses untuk meningkatkan kualitas pendidikan dapat dimulai dari menganalisis setiap komponen yang dapat membentuk dan memengaruhi proses pembelajaran. Namun demikian, komponen yang selama ini dianggap sangat memengaruhi proses pendidikan adalah komponen guru. ( Sanjaya: 2006).

Sejak awal kehidupan manusia terlibat dengan kegiatan belajar yang tak terhitung jumlahnya, mulai dari hal-hal yang sederhana sampai kepada belajar menguasai hal-hal yang kompleks dan canggih.Cakupan jenis belajar meliputi hal-hal yang bersifat pengetahuan, keterampilan, maupunbelajar menyikapi nilainilai yang diperoleh seseorang melalui pergaulan(A.Suhaenah Suparno, 2011:1).Guru adalah pihak yang bertugas membimbing peserta didik agar dapat mencapai tujuan pembelajaran sekaligus mengelola kelas agar dapat menjadi sebuah tim yang solid, komunikatif,dan kondusif selama proses pembelajaran.

Berdasarkan pengalaman selama PPL di SMA N 2 Tondano, ditemukan beberapa kendala pada saat peserta didik menerima pelajaran.Misalnya peserta didik cepat bosan saat menerima pelajaran, mudah mengantuk, berbicara dengan teman-temannya di luar materi yang sedang dibahas dalam pembelajaran, guru kadang-kadang hanya fokus pada satu peserta didik saja sehingga peserta didik lain merasa terabaikan.Disamping itu, peserta didik masih menganggap fisika adalah salah satu mata pelajaran yang dianggap sangat sulit untuk dipelajari karena banyaknya rumus yang harus dipahami.Anggapan tersebut dibuktikan dengan pendapat peserta didik bahwa pelajaran fisika itu harus menguasai semua rumus dan pelajaran yangmembosankan untuk dipelajari.
Salah satupenyebabnya karena pembelajaran fisikamerupakan pembelajaran konvensional, sehingga peserta didik kurang dapat memahami secara luasmateri pelajaran yang diberikan pendidik dan juga peserta didik kurang antusias dalammengikuti pembelajaran sehingga kurang meningkatnya keaktifan, kreatifitas serta keterampilan peserta didik.Akibatnya nilai-nilai yang didapatkan saat ujian fisika sangatlah rendah dan di bawah Kriteria Ketuntasan Minimal (KKM).

Berdasarkan pengalaman tersebut peneliti ingin mencoba metode pembelajaran yang bisa melibatkan peserta didik lebih dalam pembelajaran sehingga peserta didik menjadi tertarik dalam mengikuti pelajaran fisika dan salah satu solusinya dengan menerapkan model pembelajaran Project-Based Learning (PjBL) .

Project Based Learning dilatarbelakangi oleh teori konstruktivistik yang menyediakan banyak kesempatan bagi peserta didik untuk menciptakan lingkungan belajar yang aktif (Cakici: 2013). Project Based Learning (PjBL) merupakan sebuah model yang mengatur proses pembelajaran melalui kegiatan proyek. Peserta didik dilibatkan untuk menyelesaikan permasalahan serta mengambil keputusan melalui berbagai kegiatan untuk memudahkan proses penyimpanan memori kognitif secara lebih permanen (Thomas, 2000). Dalam Project Based Learning, peserta didik diajak untuk menyelesaikan permasalahan yang tidak mudah ditemukan jawabannya. Kriteria PjBL menurut Tamim (2013) adalah proyek harus sesuai dengankurikulum, fokus pada masalah yang mengajak peserta didik untuk menghubungkan dengan konsep utama, melibatkan peserta didik untuk melakukan pengamatan yang kontruktivis, realistis, dan mandiri.

Materi fisika usaha dan energi merupakan salah satu materi yang diajarkan pada peserta didik kelas X semester 2 . Ada banyak peristiwa yang berhubungan dengan usaha dan energi dalam kehidupan sehari-hari. Berbagai peristiwa tersebut kemudian akan memberikan pertanyaan besar yang mendasari pemikiran peserta didik, mengapa hal itu dapat terjadi dan apa yang terjadi pada benda-benda tersebut. Pada materi usaha dan energi peserta didik dapat diarahkan untuk dapat menyelesaikan permasalahan dengan merancang sebuah proyek dengan menerapkan prinsip usaha dan 
energi pada kehidupan sehari- hari.

Berdasarkan berbagai uraian diatas, maka perlu diterapkan model pembelajaran Project Based Learning yang dapat meningkatkan partisipasi aktif peserta didik agar hasil belajarnya meningkat yang diangkat dalam penelitian dengan judul "Penerapan Model Pembelajaran Project Based Learning untuk Meningkatkan Hasil Belajar Fisika dan Keterampilan Proses Sains Peserta Didik Kelas X SMA N 2 Tondano"

\section{METODE PENELITIAN}

\section{Desain Penelitian}

Pada penelitian penerapan model pembelajaran $\mathrm{PjBL}$ akan dilaksanakan dengan menggunakan metode penelitian tindakan kelas (PTK). Secara garis besar penelitian terdiri dari empat tahapan, yaitu perencanaan (planning), tindakan (action), pengamatan (observation), dan refleksi (reflection).

Tahap perencanaan (planning) merupakan tahap awal setelah diperoleh gambaran umum tentang kondisi, situasi pembelajaran di kelas, dan lingkungannya dapat dikenali dengan baik.

Tahap tindakan (action) merupakan penerapan skenario pembelajaran yang telah direncanakan dan terkendali serta berusaha untuk memperbaiki keadaan.

Tahap pengamatan (observation) dilakukan oleh guru mata pelajaran fisika dan dibantu oleh beberapa pengamat. Pengamatan Pada tahap pengamatan (observation) dilakukan oleh guru mata pelajaran fisika.

Tahap refleksi (reflection) ini merupakantahap menganalisis pada lembar respon pesertadidik yang kemudian akan digunakan sebagairefleksi.

\section{Waktu dan Tempat Penelitian}

Penelitian ini dilaksanakan pada semester genap tahun ajaran 2019/2020 di SMA N 2 Tondano, SMA ini berada di Tondano, Kelurahan Tataaran patar, Kecamatan Tondano Selatan, Kabupaten Minahasa.

\section{Subjek Penelitian}

Subjek dari penelitian ini adalah siswa kelas X IPA berjumlah 30 peserta didik di SMA N 2 Tondano, Kabupaten Minahasa tahun ajaran 2019/2020.

\section{Instrumen Penelitian}

Instrumen yang digunakan dalam penelitian ini meliputi silabus, RPP LKPD, jurnal harian, lembar observasi keterampilan proses sains, dan lembar respon peserta didik.

\section{Teknik Analisis Data}

Analisis data untuk pre-test dan post-test menggunakan gain-test. Gain-test dicari untuk memperoleh hubungan antara nilai pre-test dan post-test (Hake, 2012).

$$
g=\frac{\text { skor posttest-skor pretest }}{\text { skor maksimum-skor pretest }}
$$

Interpretasi nilai gain disajikan dalam kriteira pada Tabel 1.

Tabel 1. Kriteria Nilai Gain

\begin{tabular}{cc}
\hline Nilai $g$ & Kriteria \\
\hline $\boldsymbol{g} \geq \mathbf{0 , 7}$ & Tinggi \\
\hline $\mathbf{0 , 3} \boldsymbol{g} \geq \mathbf{0 , 7}$ & Sedang \\
\hline $\boldsymbol{g}<\mathbf{0 , 3}$ & Rendah \\
\hline
\end{tabular}

Analisis keterampilan proses sains peserta didik dianalisis menggunakan persamaan 4.

$$
\% K P=\left(\frac{X}{N}\right) 100 \%
$$

Selanjutnya skala penilaian dan interpretasinya digunakan ketentuan disajikan pada Tabel 2.

Tabel 2. Konversi Nilai Persentase (M. Ngalim Purwanto, 2002: 103).

\begin{tabular}{cc} 
Persentase & Predikat \\
\hline $86-100 \%$ & Sangat Baik \\
\hline $76-85 \%$ & Baik \\
\hline $60-75 \%$ & Cukup Baik \\
\hline $55-59 \%$ & Kurang Baik \\
\hline $55 \%$ & $\begin{array}{c}\text { Sangat Kurang } \\
\text { Baik }\end{array}$ \\
\hline
\end{tabular}

\section{HASIL DAN PEMBAHASAN}

A. SIKLUS I

1. Tahap Perencanaan

Pada tahap perencanaan pertama-tama menentukan materi yang akan disampaikan dalamkegiatan pembelajaran. Pada siklus I materi pokok yang disampaikan tentang usaha. Selanjutnya, membuat instrumen sesuai denganmodel pembelajaran yang akan dilaksanakan. Instrumen pembelajaran yang digunakan sebagai perangkat pembelajaran terdiri dari RPP, LKPD, lembar penilaian kognitif berupa pretest dan posttest, lembar observasi keterampilan proses sains, dan lembar respon peserta didik.

2. Tahap Tindakan 
Kegiatan pembelajaran siklus I dilaksanakan dengan metode scientific learning dan metode diskusi selama 90 menit. Peserta didik dibagi dalam 5 kelompok. Pembelajaran pada siklus I diamati guru mata pelajaran fisika (observer).Langkah-langkah pembelajaran pada siklus I ini meliputi:

a) Pertanyaan Esensial

Pada tahap ini guru merangsang pengetahuan awal peserta didik melalui pemberian pretest dan pertanyaan esensial. Pertanyaan esensial yang diberikan adalah "Berapa usaha yang dilakukan ketika seseorang mendorong tembok? Kenapa usahanya bisa nol?".

b) Perencanaan

Guru memberikan penjelasan tentang skenario pembelajaran, tujuan pembelajaran, dan indikator pembelajaran yangakan dicapai. Proyek pembelajaran yang diberikan berupa merancang proyek percobaan. Sebagai panduan proses pembelajaran, guru memberikan LKPD yang berisi panduan dalam melaksanakan proyek percobaan.

c) Jadwal

Pertemuan pertama dilaksanakan Kamis,27 Februari 2020. Selama 30 menit pertama peserta didik melakukan pretest dan pembagian kelompok kemudian dilanjutkan dengan mekasanakan proyek siklus I materi usaha selama 60 menit. Pertemuan kedua dilaksanakan Selasa 03, Maret 2020. Selama 30 menit pertama peserta didik melakukan posttest untuk pertemuan sebelumya yang telah dilaksanakan, kemudian dilanjutkan dengan menjawab pertanyaan refleksi selama 5 menit selanjutnya guru menjelaskan dan menerangkan sedikit tentang materi dan memberi arahan untuk melaksanakan proyek pada keesokan harinya selama 10 menit.

\section{d) Pengawasan}

Pada tahap ini guru bertanggung jawab mempersiapkan peralatan yang dibutuhkan selama proses pembelajaran dan melakukan pengawasan dalam pelaksanaannya. Dalam hal ini guru menyediakan alat-alat percobaan yang akan digunakan untuk melaksanakan kegiatan proyek siklus I.

e) Penilaian

\section{1) Pretest dan Posttest}

Persentase ketercapaian peserta didik dalam hasil belajar fisika dijabarkan dalam Tabel 3.
Tabel 3. Persentase Ketercapaian Hasil Belajar Fisika Siklus I

\begin{tabular}{|c|c|c|c|c|}
\hline \multirow{2}{*}{$\begin{array}{c}\text { Jenis } \\
\text { Tes }\end{array}$} & \multicolumn{3}{|c|}{$\begin{array}{c}\% \\
\text { KP }\end{array}$} & \multirow{2}{*}{$\begin{array}{l}\text { Standar } \\
\text { Deviasi }\end{array}$} \\
\hline & Min & Max & Rerata & \\
\hline Pretest & 27 & 52 & 42,9 & 7,74 \\
\hline Posttest & 50 & 80 & 67,4 & 8,08 \\
\hline
\end{tabular}

Untuk memperoleh hubungan antara nilai pretest dan posttest dicari dengan menggunakan gain-test. Pada Tabel 4 ditunjukkan hubungan nilai pretest dan posttest.

Tabel 4. Analisis Gain-test

\begin{tabular}{cccc}
\hline $\begin{array}{c}\text { Rerata } \\
\text { Pretest }\end{array}$ & $\begin{array}{c}\text { Rerata } \\
\text { Posttest }\end{array}$ & $\begin{array}{c}\text { Sandar } \\
\text { Gain }(\boldsymbol{g})\end{array}$ & Kriteria \\
42,9 & $\mathbf{6 7 , 4}$ & $\mathbf{0 , 4 3}$ & Sedang \\
\hline
\end{tabular}

Terlihat bahwa hubungan antara nilai pretest dan posttest dengan menggunakan gaintest sebesar 0,43 dan memiliki kriteria sedang. Hasil rata-rata pretest sebesar 42,9 dan rata-rata posttest sebesar 67,4 sehingga ada kenaikan sebesar 24,5 poin, sedangkan peserta didik yang tuntas belajar sebesar 16,67\%. Hasil tersebut dapat dilukiskan seperti Gambar 1.

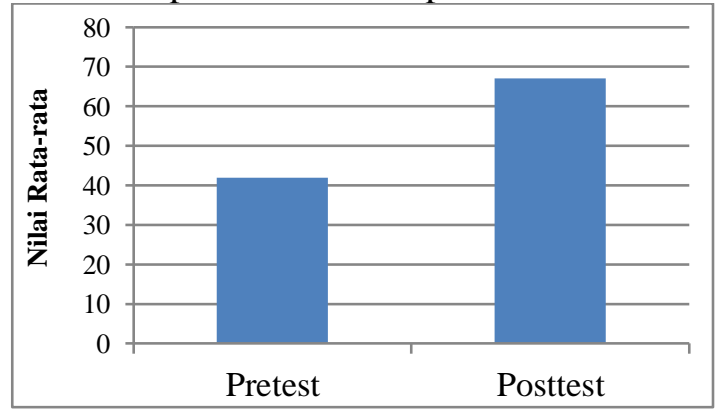

Gambar 1. Nilai Rata-rata Test Kognitif Siklus I.

2) Keterampilan Proses Sains

Penilaian keterampilan proses sains dilakukan pada saat peserta didik mengamati, menyusun hipotesis, melakukan eksperimen, mengklasifikasi data ke dalam tabel, interpretasi data, menyimpulkan, dan mengomunikasikan. Aspek keterampilan proses sains peserta didik pada siklus I memiliki kategori baik.

Gambar 2 merupakan hasil dari presentase keterampilan proses sains siklus I yang diamati oleh observer. 


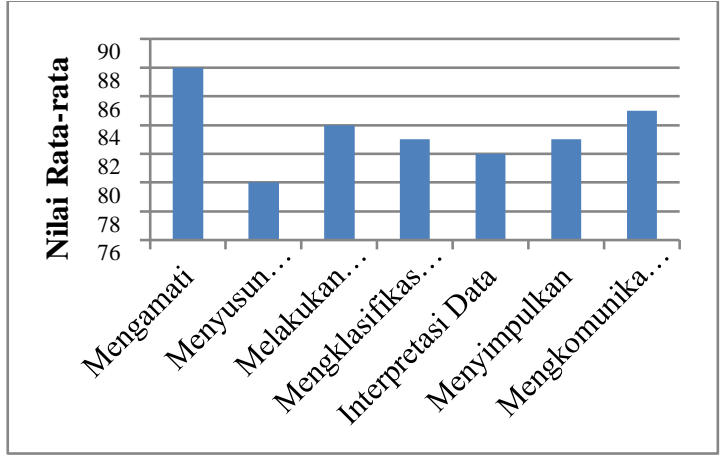

Gambar 2. Persentase Keterampilan Proses Sains Siklus I

f) Evaluasi

Berdasarkan lembar respon peserta didik tersebut, dapat diketahui bahwa pesesrta didik menyukai model pembelajaran Project Based Learning.

\section{Tahap Pengamatan}

Berdasarkan pengamatan pada siklus I berlangsung diperoleh beberapa hal yang menjadiperhatian, di antaranya:

a) Pengamatan kerjasama antar peserta didik dalam kelompok masih kurang, sehingga dalam mengerjakan proyek hanya didominasi oleh beberapa peserta didik saja.

b) Perilaku peserta didik saat mengerjakan soal pretest dan posttest masih banyak yang bekerjasama dalam mengerjakannya serta pesertadidik juga sibuk sendiri.

c) Hasilbelajardapatdiketahuipeningkatannya dengan dilakukan pembelajaran dengan model Project based learning rata-ratanya menjadi 67,4 .

\section{Tahap Refleksi}

Berdasarkan hasil diskusi antara guru mata pelajaran, peneliti, dan observer didapatkan hasil refleksi sebagai berikut:

a) Peserta didik masih kebingungan dalam merancang percobaan dan diskusi sehingga masih membutuhkan bimbingan.

b) Kerja sama peserta didik masih kurang, dalam pengerjaan proyek hanya didominasi olehbeberapa peserta didik saja.

c) Pada akhir pembelajaran menghendaki guru mengulang kembali materi yang telah dipelajari sehingga para peserta didik benarbenar jelas dalam memahami materi.

\section{B. SIKLUS II}

\section{Tahap Perencanaan}

Peneliti menentukan materi yang akan disampaikan yaitu materi pokok energi yang terdiri dari energi potensial, energi kinetik dan energi mekanik.

\section{Tahap Tindakan}

Proses belajar mengajar diawali setelah pesertadidik telah menempatkan diri pada kelompoknya, kemudian guru membuka pembelajaran dengan salam dan presensi peserta didik. Langkah- langkah pembelajaran pada siklus II ini meliputi:

a) Pertanyaan Essensial

Guru juga memberikan pertanyaan esensial yang berkaitan dengan materi yang akan dipelajari. Pertanyaan esensial yang diberikan adalah "Mengapa setelah melakukan sejumlah aktivitas tubuh kita terasa lemas? Dapatkah manusia menciptakan energi?".

b) Perencanaan

Proyek pembelajaran yang diberikan berupa merancang percobaan materi pokok energi. Sebagai panduan proses pembelajaran, guru memberikan LKPD siklus II yang berisi panduan dalam melaksanakan proyek percobaan. Peserta didik membaca LKPD siklus II yang telah dibagikan dan berdiskusi untuk melaksanakan proyek yang telah tersedia pada LKPD.

c) Jadwal

Pertemuan pertama dilaksanakan pada Kamis, 23 Februari 2020, selama 30 menit pertama peserta didik melakukan pretest kemudian dilanjutkan dengan melaksanakan proyek siklus II materi energi selama 60 menit. Pertemuan kedua dilaksanakan pada Rabu 01 Maret 2020, selama 30 menit pertama peserta didik melakukan posttest untuk pertemuan sebelumnya yang telah dilaksanakan, kemudian dilanjutkan dengan menjawab pertanyaan respon peserta didik pembelajaran selama 5 menit. Guru menjelaskan sedikit tentang materi yang telah dipelajari dalam proyek sekaligus untuk memperdalam materi selama 10 menit.

d) Pengawasan

Pada tahap ini guru bertanggung jawab mempersiapkan peralatan yang dibutuhkan selama proses pembelajaran dan melakukan pengawasan dalam pelaksanaannya. Dalam hal ini guru menyediakan alat-alat percobaan yang akan digunakan untuk melaksanakan kegiatan proyek siklus II.

e) Penilaian

\section{1) Pretest dan Posttest}

Pada siklus II, persentase ketercapaian hasil belajar fisika peserta didik dijabarkan dalam 
Tabel 5.

Tabel 5. Persentase Hasil Belajar Siklus II

\begin{tabular}{|c|c|c|c|c|}
\hline & & $\begin{array}{c}\text { \% } \\
\mathrm{K}\end{array}$ & & \\
\hline Tes & Min & Max & Rerata & Deviasi \\
\hline Pretest & 35 & 67 & 48,9 & 9.53 \\
\hline Posttest & 67 & 100 & 82,7 & 6.88 \\
\hline
\end{tabular}

Untuk memperoleh hubungan antara nilai pretest dan posttest dicari dengan menggunakan gain-test. Pada Tabel 6 ditunjukkan hubungan nilai pretest dan posttest.

\begin{tabular}{cccc} 
& \multicolumn{3}{c}{ Tabel 6. Analisis Gain-test } \\
Rerata & Rerata & Sandar & Kriteria \\
Pretest & Posttest & Gain $(\mathbf{g})$ & \\
$\mathbf{4 8 , 9}$ & $\mathbf{8 2 , 7}$ & $\mathbf{0 , 5 1}$ & Sedang \\
\hline
\end{tabular}

Terlihat bahwa nilai pretest danposttest dengan menggunakan gain-test sebesar 0,51 dengan kriteria sedang. Skor rata-rata pretest sebesar 48,9 dan posttest sebesar 82,7 dengan kenaikan pretest ke posttest sebesar 33,8poin, sedangkan peserta didik yang tuntas belajar mencapai $83,34 \%$. Hasil tersebut dapat dilihat pada Gambar 3.

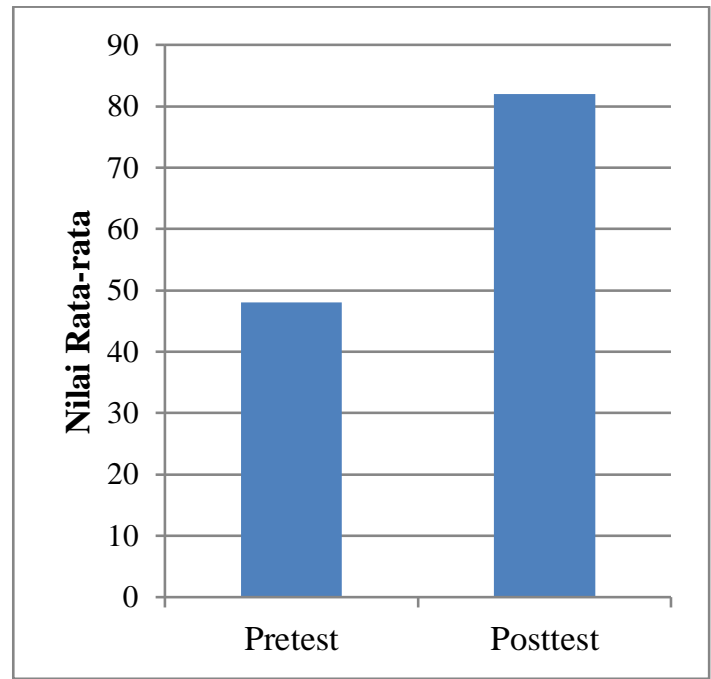

Gambar 3. Nilai Rata-rata Test Kognitif Siklus II

2) Keterampilan Proses Sains

Penilaian keterampilan proses sains ini meliputi peserta didik saat mengamati, menyusun hipotesis, melakukan eksperimen, mengklasifikasi data kedalam tabel, interpretasi data, menyimpulkan, dan mengomunikasikan. Persentase keterampilan proeses sains memiliki kategori sangat baik. Hasil dari presentase keterampilan proses sains siklus II yang diamati oleh observer dapat dilihat pada Gambar 4.

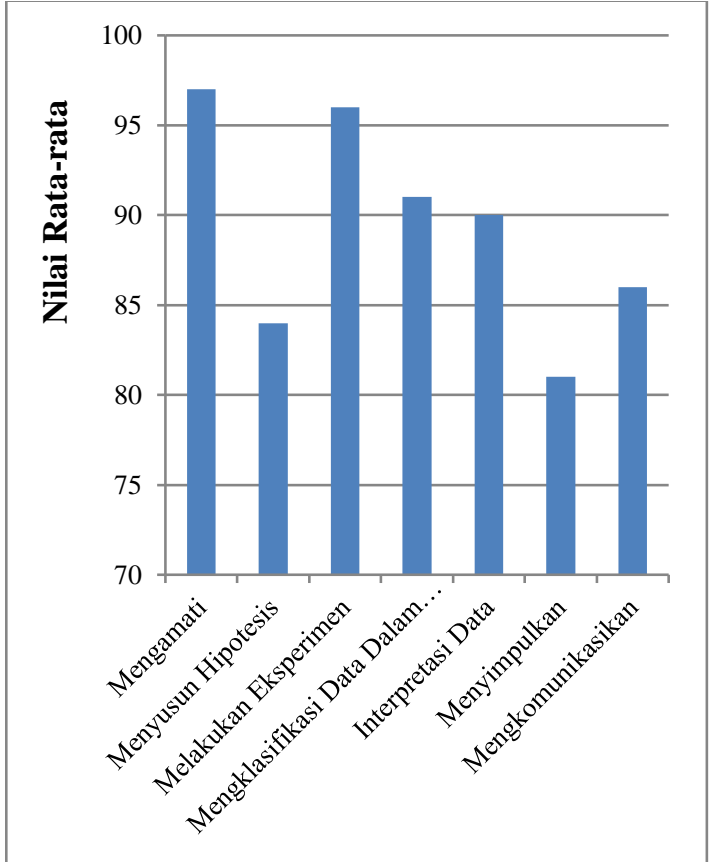

Gambar 4. Presentase Keterampilan Proses Sains Siklus II

f) Evaluasi

Proses evaluasi dilakukan dengan cara peserta didik diminta untuk mengisi lembar respon peserta didik. Proses evaluasi juga dilakukan dengan cara guru melakukan diskusi dengan guru mata pelajaran, peneliti, dan observer.

\section{Tahap Pengamatan}

Berdasarkan pengamatan saat siklus II berlangsung didapatkan beberapa hal yang menjadi perhatian, diantaranya:

a) Kerjasama antar peserta didik dalam kelompok sudah mulai mengalami kemajuan, sehingga dalam pengerjaan proyek percobaan sudah hampir semua peserta didik terlibat dalam diskusi maupun pengerjaan proyek percobaan.

b) Dampak perlakuan siklus II yang diawali dengan perencanaan, tindakaan dan pengamatan berpengaruh pada diri peserta didik. Pengaruh tersebut dapat dilihat pada hasil nilai tes yang dilakukan. Hasil belajar dapat diketahui peningkatannya yaitu pada nilai siklus I dilakukan pembelajaran rataratanya 67,4 dengan nilai siklus II rataratanya menjadi 82,7 .

\section{Penghentian Siklus}

Pada siklus ini telah terjadi peningkatan hasil belajar fisika peserta didik dari aspek kognitif dan peningkatan keterampilan proses sains. Peningakatan hasil belajar tersebut dapat 
dilihat pada Tabel 7 dan gambar 5.

Tabel 7. Rangkuman Pencapaian Nilai

\begin{tabular}{cccccc}
\multirow{2}{*}{$\begin{array}{c}\text { Hasil } \\
\text { Belajar }\end{array}$} & \multicolumn{4}{c}{ Nilai Hasil Belajar } \\
\cline { 2 - 6 } & Maks & Min & $\begin{array}{c}\text { Rata- } \\
\text { rata }\end{array}$ & \multicolumn{2}{c}{ Nilai $\geq 75$} \\
\hline $\begin{array}{c}\text { Siklus } \\
\text { I }\end{array}$ & 80 & 50 & 67,4 & $\begin{array}{c}5 \text { peserta } \\
\text { didik }\end{array}$ & $16,6 \%$ \\
\hline $\begin{array}{c}\text { Siklus } \\
\text { II }\end{array}$ & 100 & 67 & 82,7 & $\begin{array}{c}\text { 25peserta } \\
\text { didik }\end{array}$ & $83,3 \%$ \\
& & & & &
\end{tabular}

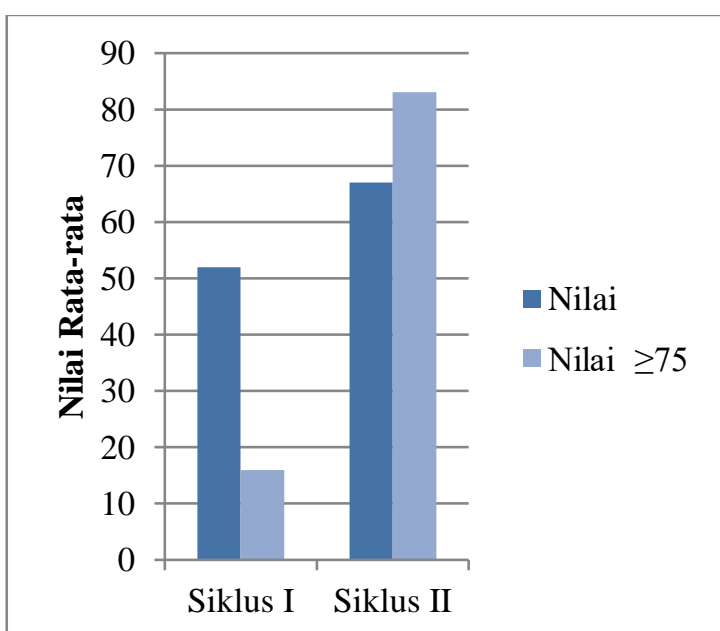

Gambar 5. Rangkuman Hasil Belajar Peserta didik Kelas X IPA

Peningkatan keterampilan proses sains dapat dilihat pada gambar 6 .

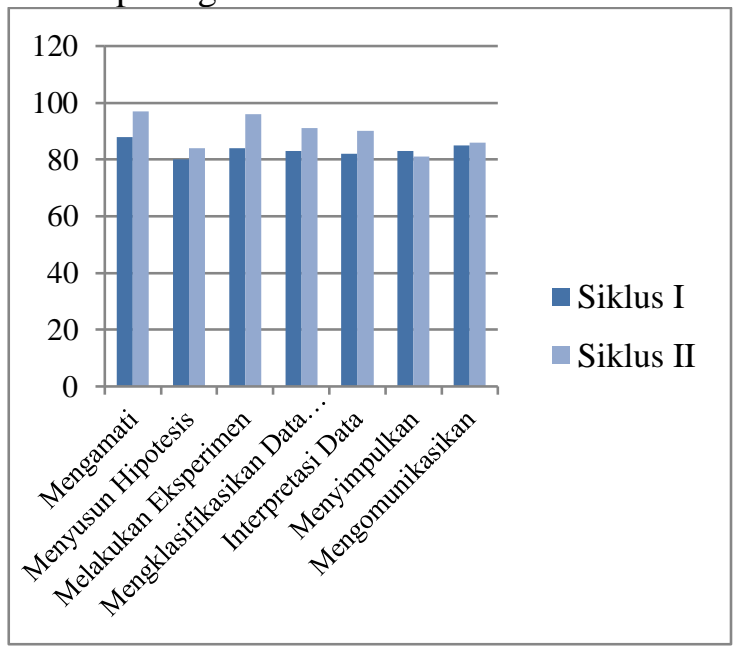

Gambar 6. Rangkuman Penilaian Keterampilan Proses Sains

Proses pembelajaran pada siklus I peserta didik masih kebingungan dalam merancang percobaan dan kerja sama antar kelompok masih kurang dikarenakan baru pertama kalinya diterapkan model pembelajaran tersebut, tetapi pada siklus II siswa sudah mulai terbiasa dalam melakukan percobaan dan kerja sama antar kelompok sudah mulai terbentuk sehingga pembelajaran lebih kondusif.

Tercapainya hasil belajar fisika dan keterampilan proses sains peserta didik maka dapat disimpulkan bahwa pembelajaran atau tindakan yang telah dilakukan dapat meningkatkan hasil belajar fisika dan keterampilan proses sains. Dengan demikian tindakan penelitian sudah dapat dihentikan.

\section{KESIMPULAN}

Besar peningkatan hasil belajar fisika dapat dilihat dari besar nilai kognitif. siklus I nilai rata-rata pretest 42,9 dan rata-rata posttest 67,4 nilai gain-test yang didapatkan sebesar 0,43 dengan kategori sedang serta pada siklus II merupakan nilai posttest tertinggi yang dicapai yaitu rata-rata pretest 48,9 dan rata-rata posttest 82,7 nilai gain-test yang didapatkan sebesar 0,51 dengan kategori sedang. Sedangkan selisih antara nilai rata-rata posttest dan pretest pada siklus I sebesar 24,5 poin dan siklus II sebesar 33,8 poin. Hal tersebut menunjukkan bahwa terdapat peningkatan hasil belajar fisika dari siklus I ke siklus II.

Peningkatan keterampilan proses sains siklus I nilai rata-rata sebesar 84,7 dengan kategori baik sedangkan siklus II didapatkan nilai rata-rata sebesar 89,9 dengan kategori sangat baik. Hal tersebut menunjukkan terdapat peningkatan keterampilan proses sains peserta didik dari siklus I ke siklus II.

\section{REFERENSI}

A Suhaenah Suparno. 2011. Membangun Kompetensi Belajar. Direktorat Jendral Pendidikan Tinggi Departemen Pendidikan Nasional.

Cakici, Y. 2013 An Investigation of the Effect of Project-based Learning Approach on Children's Achievement and Attitude in Science,3 (1):9-17

Eeeva Reeder. 2007. The PBL Launch Pad: WorthwhileProjectsfor High

School Students,Part1. Diakses dari http://www.edutopia.org/designingworthwhile-pbl-project-high-schoolstudents-part-1.17 Januari 2019.

Mundilarto. 2010. Penilaian Hasil Belajar 
Fisika. Yogyakarta: P2IS FMIPA UNY Press.

Ngalim Purwanto. (2002). Prinsip-Prinsip dan Teknik Evaluasi Pengajaran. Bandung: PT. Remaja Rosdakarya.

Tamim \& Michael M. G. Definitions and Uses: Case Study of Teachers Implementing Project-based Learning. Interdisciplinary Journal of Problem-based Learning.

Thomas, J. W. 2000. A Review of Research on ProjectbasedLearning.Diaksesdarihttp:// www.bobpearlman.org/BestPractices/PB L_Research.pdf.

Wina Sanjaya. 2006. Strategi Pembelajaran: Berorientasi Standar Proses Pendidikan. Jakarta: Kencana Prenada

Yamin \& Antasari. 2008.TeknikMengembangkan Kemampuan Individu Siswa. Jakarta: GP Press 